\title{
REPRESENTASI MULTIKULTURALISME DALAM SEPAK BOLA PRANCIS MASA KINI
}

\author{
Fadli Muhammad Athalarik $^{1 *}$ dan Arif Susanto ${ }^{2}$ \\ 1,2Institut Komunikasi dan Bisnis LSPR, Jakarta, Indonesia. \\ *fadli.athalarik@gmail.com
}

\begin{abstract}
The arrival of a large number of immigrants made France feel such a huge impact, one of which is the presence of a multicultural situation in French society. One portrait of multiculturalism that deserves the spotlight is football. This study aims to determine the cultural diversity in French society and how multiculturalism is represented in French football. The research method in this research is descriptive qualitative. To analyze this phenomenon, researchers used the Concept of Multicultural and Cross-Cultural Communication. The results of this study stated that in the field of football, multiculturalism can be said to be a gift, because with the presence of many immigrants, France won a lot of glory on the European and World soccer stage. However, on the other hand, the arrival of Multiculturalism in France, faced many challenges and problems in it. The impact caused by multiculturalism is not a small impact, from the existence of crime and terrorism, to the problems present in society such as Islamophobia, xenophobia, anti-semitism and so forth.
\end{abstract}

Keywords: Multiculturalism, Immigrants, Football.

\begin{abstract}
Abstrak
Kedatangan imigran dengan jumlah yang masif membuat Prancis merasakan dampak yang begitu besar, dampak yang dirasakan salah satunya adalah hadirnya situasi multikultural dalam masyarakat Prancis. Salah satu potret multikulturalisme yang patut menjadi sorotan ialah sepak bola. Penelitian ini bertujuan untuk mengetahui keberagaman budaya dalam masyarakat Prancis dan bagaimana multikulturalisme direpresentasikan dalam sepak bola Prancis. Metode Penelitian dalam penelitianini ialah kualititatifdeskriptif. Untuk menganalisa fenomena tersebut, peneliti menggunakan Konsep Multikultural dan Komunikasi Lintas Budaya. Hasil penelitian in menyatakan bahwa dalam bidang sepak bola, multikulturalisme bisa dikatakan sebagai anugerah, karena dengan hadirnya banyak imigran, Prancis meraih banyak kejayaan di pentas sepak bola Eropa maupun Dunia. Namun, disisi lain, kedatangan Multikulturalisme di Prancis , mendapat banyak tantangan dan permasalahan di dalamnya. Dampak yang diakibatkan oleh multikulturalisme bukanlah dampak yang kecil, dari adanya kriminalitas dan terorisme, hingga permasalahan yang hadir dalam masyarakat seperti islamophobia, xenophobia, anti semitisme dan lain sebagainya.
\end{abstract}

Kata Kunci : Multikulturalisme, Imigran, Sepak Bola.

\section{PENDAHULUAN}

Konsep Multikulturisme adalah sebuah keadaan dimana masyarakat berada dalam situasi yang terpola rapi dari beragam latar belakang budaya (etnis, suku, ras, warna kulit), dalam situasi yang mana setiap individu yang berada di lingkungan tersebut merasa aman dan nyaman, sehingga yang terjadi adalah suasana yang tidak memiliki kecemasan atau tanpa adanya sebuah usahas pertahanan diri dalam pengalaman pertemuan antarbudaya (Muhdaliha \& Arlena, 2017).

Multikulturalisme sendiri teraplikasikan dalam kehidupan masyarakat di Eropa, khususnya di Prancis. Sejarah mencatat bahwa multikulturalisme telah terjadi pada 
masa periode perang dunia, baik pertama maupun kedua, yang dimana puncaknya saat pasca perang dunia kedua. Permasalahan yang membuat banyaknya imigran datang ialah diceritakan pada saat itu Prancis harus menghadapi situasi kurangnya jumlah tenaga kerja. Sehingga banyak imigran yang kebanyakan dari Negara jajahan Prancis datang ke Prancis untuk mencari pekerjaan. Banyak dari imigran tersebut yang membawa keluarga mereka dan tinggal di Prancis. Keberagaman yang terjadi akibat proses imigrasi menjadikan Prancis sebuah negara multikultur (Ismoyo, 2017).

Hingga Pasca Perang Dunia II, Negaranegara tetangga seperti Portugal, Italia, dan Spanyol menjadi kontributor terbesar dari kedatangan imigran ke Prancis, tetapi arus imigran baru-baru ini datang dari Afrika Utara, khususnya Aljazair (bagian integral dari Prancis hingga 1962) dan bekas protektorat Maroko dan Tunisia. Orang-orang dari wilayah Prancis atau bekas Perancis di Afrika Tengah, Asia, dan Amerika memberikan sumber tambahan imigran. Dengan jumlah imigran yang terus bertambah, hal tersebut menciptakan masyarakat yang multikultural di Prancis (Bernard, et al., 2019).

Pertumbuhan jumlah imigran yang semakin banyak, sehingga menjadi suatu fokus topik yang penting di Prancis karena kehadiran imigran tersebut memberikan dampak pada aspek-aspek krusial di Prancis, seperti sosial, politik, dan budaya. Gesekan budaya seperti kasus rasial antara penduduk asli terhadap imigran terjadi sedari kehadiran imigran hingga saat ini. Kesenjangan sosial juga terjadi antara penduduk setempat dan imigran, sehingga menimbulkan gesekan sosial yang berujung konflik dalam hubungan keduanya. Masalah ini juga berdampak pada aspek politik, partai ekstrim kanan yang cenderung nasionalis bersikap xenophobia. Mereka menyerukan adanya penolakan imigran karena dianggap mengganggu stabilitas masyarakat Prancis. Ketakutan akan pendatang sudah menjadi momok bagi sebagian masyarakat Prancis (Ismoyo, 2017).

Selain itu, aspek ekonomi ikut menjadi daya tarik tersendiri bagi kaum imigran untuk bekerja dan tinggal di Perancis. Banyak kaum imigran yang ingin memperbaiki nasibnya sehingga memutuskan untuk bermigrasi ke Perancis. Biasanya, para imigran cenderung ditempatkan pada sektor industri yang memerlukan tenaga fisik secara besar seperti menjadi buruh bangunan karena banyak dari imigran ini berasal dari Afrika. Ini menjadi keuntungan bagi pemilik modal dan pengusaha yang ada di Perancis karena mereka mampu memonopoli para kaum imigran sehingga mudah untuk para pemilik modal dalam mencari tenaga kerja yang murah dan mudah diajak bekerjasama ke dalam usaha mereka. (Wicaksono, 2017). Namun, ketika ekonomi sedang menurun, imigran turut dikambinghitamkan dan kerap terjadi xenophobia, hal tersebut dilakukan dengan kedok melindungi para pekerja dan budaya, Ini terjadi selama stagnasi ekonomi tahun 1880-an / 1890-an dan 1930-an (Krasnoff, 2016)

Di balik rumitnya permasalahan imigran yang terjadi di Prancis, imigran tersebut menemukan jalan alternatif untuk mereka bisa terintegrasi dengan masyarakat Prancis, yakni dengan sepak bola. Sepak bola justru menjadi sebuah kendaraan bagi para imigran untuk berintegrasi. Jika berkaca apa yang terjadi pada tahun 1998, Timnas Prancis yang memenangkan Piala Dunia kerap disebut sebagai tim "blackblanc-beur" (keturunan kulit hitam-kulit putih-arab). Tim inilah yang kerap disebut sebagai lambang keberagaman dan integrasi. Hal tersebut dikarenakan keberhasilan para imigran dan keturunannya untuk berintegrasi dengan kultur Prancis dan tekad dari masyarakat Prancis untuk membuka diri kepada para imigran. Sehingga mampu menghadirkan trofi Piala Dunia FIFA 1998 ke pelukan Prancis saat itu Terlebih memang sudah banyak yang menyadari bahwa Prestasi Prancis dari dahulu itu bergantung pada kehadiran para pemain imgran itu sendiri (Hindratmo, 2018) . 
Terlepas dari prestasi yang didapat oleh timnas Prancis yang memiliki keberagaman, masih banyak permasalahan yang terjadi dalam persepakbolan Prancis. Sepertinya ada penolakan dari pemerintah yang berbasis dari partai sayap kanan prancis, bahkan sepak bola juga tak luput dari adanya kasus rasial seperti diskriminasi. Fakta-fakta tersebut yang membuat peneliti tertarik untuk meneliti representasi multikultural yang terjadi dalam kehidupan sepak bola Prancis.

Konteks dari penelitian ini mengacu pada keberagaman latar belakang budaya yang dimiliki persepakbolaan Prancis, yang didominasi oleh pemain berketurunan Afrika. Berdasarkan penjelasan tersebut maka penulis memilih judul "Representasi Praktik Multikulturalisme dalam Sepak Bola Prancis".

Dalam penelitian ini, Peneliti memberikan batasan ruang dan waktu. Peneliti hanya meneliti atau membahasan mengenai sepak bola di Negara Prancis dan aplikasinya terhadap konsep multikulturalisme. Selain itu, Peneliti juga meneliti Sepak bola Prancis dalam kurun waktu 22 tahun terakhir terhitung dari tahun 1998, saat Prancis memenangkan Piala Dunia FIFA 1998.

Dalam penelitian ini penulis memfokuskan pembahasan kepada situasi Multikulturalisme yang direpresentasikan dalam kehidupan persepakbolaan Prancis, baik dari sejarah, proses perekrutan, adanya permasalahan yang terjadi di dalamnya hingga upaya penyelesaian dari permasalahan tersebut.

Berdasarkan latar belakang permasalahan diatas, maka penulis mengemukakan perumusan masalah sebagai berikut: Bagaimana Praktik Multikulturalisme terepresentasikan dalam Sepak Bola Prancis Masa Kini?

Berdasarkan permasalahan diatas, maka tujuan penelitian ini ialah Untuk mengkaji praktik multikulturalisme terepresentasikan dalam sepak bola Prancis masa kini.

Penelitian seperti ini pernah dilakukan oleh beberapa peneliti lainnya (dalam bentuk jurnal), diantaranya adalah Petsy Jessy Ismoyo dan Moddie Alvianto Wicaksono, dan juga beberapa penelitian yang dilakukan oleh peneliti terdahulu. Peneliti terdahulu mengangkat permasalahan keberagaman latar belakang budaya di Prancis untuk dijadikan topik pembahasan peneliti tersebut, hanya saja, Belum ada peneliti yang menitikfokuskan topik keberagaman latar belakang budaya multikulturalisme di Prancis terhadap bidang sepak bola. Berikut data dan informasi yang didapatkan oleh peneliti

Dalam jurnal yang berjudul "Islamofobia di Prancis: Diskiriminasi Perempuan Muslim Magrhibi karangan Petsy Jessy Ismoyo. Peneliti ingin mencoba untuk menunjukkan hubungan antara identitas, konteks Islam, dan diskriminasi. Penulis mencoba menganalisis penyebab dan dampak diskriminasi terhadap identitas Perempuan Moeslem Maghribi. Diskriminasi difokuskan pada kesulitan mencari pekerjaan (Ismoyo, 2017).

Selanjutnya, Dalam jurnal yang berjudul "Dinamika Imigran Muslim di Perancis melalui Ruang Publik pada Pemerintahan Nicholas Sarkozy" karangan Moddie Alvianto Wicaksono. Penelitian ingin menunjukkan Pemerintahan Sarkozy berupaya mengendalikan populasi imigran muslim dengan cara mengeluarkan kebijakan French Immigration and Integration Law. Implikasi dengan dikeluarkannya kebijakan tersebut berupaya untuk mempersempit akses imigran muslim dalam mengakomodir ruang publik. Ruang publik yang sejatinya dapat diakses oleh siapapun namun kenyatannya gerak dari imigran muslim terbatas. Hal ini menyebabkan terjadinya segregasi antara imigran muslim yang ada di Perancis dengan pemerintahan Perancis dan masyarakat kulit putih asli Perancis (Wicaksono, 2017).

Konsep utama yang digunakan dalam penelitian ini ialah multikulturalisme. Konsep multikulturalisme sebagai sebuah pengakuan bahwa beberapa kultur yang berbeda dapat hidup dalam lingkungan yang 
sama dan menguntungkan satu sama lain, atau multikulturalisme dianggap sebagai alat untuk menetapkan keyakinan terhadap terhadap adanya keberagaman budaya. Selain itu, multikulturalisme menghargai dan berusaha melindungi keragaman kultural (Mubit, 2016).

Konsep multikulturalisme tidak dapat disamakan dengan konsep keanekaragaman suku bangsa atau kebudayaan yang menjadi ciri khas masyarakat majemuk. Multikulturalisme menegaskan kepada aspek keanekaragaman kebudayaan dalam kesetaraan. Multikulturalisme juga menyinggung berbagai ranah permasalahan yang bersinggungan dengan ideologi ini, yaitu politik, demokrasi, keadilan, penegakkan hukum, kesempatan kerja dan berusaha, HAM, hak budaya komuniti, penghormatan atas golongan minoritas, prinsip-prinsip etika -moral, dan mutu produktivitas. (Dewantara, 2019).

Konsep Multikulturalisme yang terjadi saat ini merupakan sebuah respons dari pemerintah terhadap permintaan politik dari etnis minoritas yang tinggal di negara tersebut. Kebijakan resmi yang dibuat pemerintah untuk situasi multikultural saat itu ialah bertujuan untuk mengatur keberagaman budaya melalui inisiatif kemakmuran, budaya, dan keadilan sosial. Selain itu, hal ini bertujuan untuk memindahkan asimilasi dari para imigran atau orang pribumi itu sendiri, agar mampu menerima perbedaan sosial yang lebih besar (Hartley, 2010). Selain itu, terdapat tiga komponen multikulturalisme, yakni kebudayaan, pluralitas kebudayaan, dan cara tertentu untuk merespons pluralitas itu (Muhdaliha \& Arlena, 2017).

Keberhasilan Praktik multikulturalisme dalam mengatur situasi masyarakat yang mutlikultural telah dibuktikan di beberapa Negara, sebut saja Kanada dan Australia yang melakukan beberapa tahap. Pertama ialah Penekanan pada keanekaan budaya, maksudnya ialah Multikulturalisme dianggap sebagai sebuah penegasan yang baik terhadap keberagaman latar belakang budaya yang menekankan pada pentingnya menjaga sebuah budaya. Tahap kedua ialah Dimensi keadilan sosial, Maksudnya ialah bagaimana Multikulturalisme mampu memberi rasa aman dan nyaman dengan porsi yang sama kepada setiap individu yang beragam latar belakangnya tanpa memperdulikan perbedaan tersebut (Nurdin, 2015).

Terdapat karakteristik yang menggambarkan situasi dari kehidupan masyarakat multikultural ini, yaitu: Terjadinya pengelompokkan (segmentasi) ke dalam bentuk kelompokkelompok yang mempunyai latar belakang kebudayaan yang berbeda-beda satu sama lain; Memiliki sistem yang terbagi-bagi ke dalam lembaga-lembaga yang bersifat nonkomplementer; Kurang mengembangkan konsensus di antara para anggotanya terhadap nilai-nilai yang bersifat dasar; Secara relatif seringkali mengalami permasalahan di antara kelompok yang satu dengan kelompok yang lain; Secara relatif integrasi sosial tumbuh dikarenakan adanya desakan atau depedensi dalam permasalahan ekonomi; serta Adanya sistem politik yang didominasi oleh suatu kelompok atas kelompok-kelompok yang lain (Mubit, 2016).

Konsep pendukung yang digunakan dalam penelitian ini ialah Komunikasi Lintas budaya. Konsep ini menggambarkan sebuah proses penyampaian pesan di dalam satu lingkungan namun terdapat masyarakat yang bersifat majemuk, sehingga berpotensi adanya sebuah perbedaan, baik latar belakang, sifat, sikap, pendapat. Selain itu, Konsep komunikasi lintas budaya juga dianggap sebagai pemindahan sebuah ide dari dua kebudayaan atau lebih, yang berdampak bertumbuhnya sebuah kebudayaan yang sudah ada, hilangnya kebudayaan yang lama atau terciptanya sebuah budaya baru di lingkup masyarakat tersebut (Dhamayanti, 2015)

Berada dalam situasi yang mutlikultural tidak serta merta menjalani kehidupan yang mulus, terdapat beberapa permasalahan yang mampu menghambat komunikasi lintas budaya 
yang teraplikasikan dalam situasi tersebut yaitu Prasangka, Etnosentrisme, dan Stereotype. (Prayoga, 2016)

Prasangka, hambatan ini merupakan sebuah tindakan buruk dari sebuah kelompok atau individual yang menyudutkan sebuah kelompok atau individual berdasarkan dari kesalahan atau kekurangan atau keterbatasan informasi mengenai kelompok tersebut. Sehingga akan berpotensi menimbulkan anggapan atau prediksi yang negative mengenai kelompok tersebut yang padahal belum ada kebenarannya.

Etnosentrisme, hambatan ini merupakan sebuah sikap yang menganggap bahwa kelompok atau budayanya lebih baik dibandingkan kelompok lain. Terdapat perasaan yang superior dan menganggap kelompok lain tidak lebih baik dibandingkan kelompoknya.

Stereotype, hambatan ini merupakan sebuah anggapan atau penilaian terhadap seorang indvidualis ataupun sebuah kelompok yang hanya didasari melalui keyakinan kelompok tersebut ataupun persepsi yang dibangun oleh kelompok tersebut. Terdapatnya kategorisasi atau segmentasi yang terjadi saat melakukan penilaian tersebut.

\section{METODOLOGI}

Penelitian ini menggunakan metode kualitatif., definisi dari metode penelitian kualitatif ialah metode penelitian yang berlandaskan pada filsafat postpositivisme, digunakan untuk meneliti pada kondisi obyek yang alamiah, (sebagai lawannya adalah eksperimen) dalam hal ini peneliti menjadi instrumen kunci, teknik pengumpulan data dilakukan secara triangulasi (gabungan), analisis data bersifat induktif/kualitatif, dan hasil penelitian kualitatif lebih menekankan makna dari pada generalisasi (Sugiyono, 2016).

Pada penelitian ini, jenis kualitatif yang digunakan ialah kualitatif deskriptif. Pengertian Deskriptif adalah penelitian yang mencoba memahami masalah sosial yang berada pada masyarakat, baik tentang peraturan sosial yang berlaku untuk lingkungan masyarakat tersebut serta kondisi dan situasi di dalam masyarakat tersebut. Metode deskriptif ini juga menjelaskan bahwa peneliti mampu melakukan pembandingan dari sebuah fenomena fenomena yang terjadi, sehingga hal tersebut termasuk dalam studi komparatif (Nazir, 2009).

Paradigma penelitian yang digunakan dalam penelitian ini ialah Paradigma Interpretif. Paradigma interpretif ini merupakan paradigma yang menekankan pendekatan kepada sebuah aksi sosial yang memiliki makna, yang disebut makna dalam konteks pendekatan intepretif ialah makna yang dibangun secara dan juga adanya relativisme nilai. Dalam arti lain, Pendekatan interpretif lebih terfokus pada aksi sosial yang bermakna melalui observasi manusia secara terperinci dan langsung dalam latar ilmiah, supaya bisa memperoleh pemahaman dan interpretasi mengenai cara orang menciptakan dan mempertahankan dunia sosial mereka. Ilmu sosial interpretif ini memiliki beberapa variasi: hermeneutika, konstruksionisme, etnometodologi, kognitif, idealis, fenomenologis, subjektivis, dan sosiologi kualitatif (Neuman, 2017).

Teknik analisis data dalam penelitian ini dilakukan disaat berlangsungnya pengumpulan data, dan setelah selesai data telah terkumpul dalam periode tertentu. Saat wawancara dilakukan, peneliti sudah harus melakukan analisis pada jawaban yang diberikan oleh narasumber. Apabila jawaban yang diberikan oleh narasumber dirasa belum memuaskan, maka peneliti boleh untuk melanjutkan pertanyaan lagi hingga tahap tertentu, hingga data yang diperoleh dianggap kredibel. Miles dan Huberman, mengemukakan bahwa aktivitas penelitian kualitatif dilakukan secara interaktif dan berlangsung secara terus menerus sampai tuntas, agar data yang diperoleh konkrit dan jelas. Aktivitas dalam analisis data itu sendiri ialah data reduction, data display, dan conclusion / verification (Sugiyono, 2016) .

Dalam penelitian ini peneliti menggunakan teknik pengumpulan data melalui wawancara, 
literature, dan dokumentasi.Penelitimempunyai subjek penelitian, dimana menggunakan tiga narasumber sebagai target wawancara dari penelitian ini. peneliti menggunakan tiga narasumber untuk lebih memahami proses secara mendalam bagaimana multikulturalisme dapat terpalikasikan dalam sepak bola Prancis. Berikut beberapa profil mengenai narasumber yang peneliti pilih serta alasan peneliti memilihnya sebagai narasumber.

Narasumber pertama yang peneliti pilih bernama Steven Paulle yang merupakan pemain sepak bola Prancis. Narasumber merupakan Pemain berkebangsaan Prancis yang pernah bermain untuk PSM Makassar di tahun 20172018 dan Persija Jakarta pada tahun 2019 di Liga 1. Alasan pemilihan Steven Paulle sebagai narasumber dikarenakan beliau merupakan Pemain yang memiliki pengalaman di Prancis, sehingga mengetahui secara langsung situasi kehidupan sosial di Prancis khususnya Sepak Bola.

Berikutnya penulis memilih Airin Miranda sebagai narasumber dari perspektif budaya Prancis. Saat ini, narasumber merupakan dosen Sastra Prancis di Fakultas Ilmu Pengetahuan Budaya di Universitas Indonesia. Pemilih memilih Airin Miranda dikarenakan beliau berpengalaman dalam mengajar mata kuliah multikulturalisme di Prancis. Bidang tersebut berkaitan langsung dengan topik penelitian yang diteliti.

Dan yang terakhir penulis memilih Justinus Lhaksana sebagai narasumber dari perspektif Sepak Bola. Beliau adalah Sportcaster di Bein Sports Indonesia dan podcast Box2Box Indonesia.. Pemilihan beliau sebagai narasumber dikarenakan sebagai pengambilan perspektif dari sepak bola Internasional, yang dimana ini berkaitan langsung dengan topik yang dibicarakan yaitu sepak bola Prancis.

\section{HASIL DAN PEMBAHASAN}

Peneliti menemukan data bahwa pada tahun 1932, klub-klub sepak bola Prancis mencari pemain untuk memperkuat timnya, namun dikarenakan saat itu sangat kurang pemain lokal yang memiliki kemampuan mumpuni di Perancis, pada akhirnya banyak dari klub tersebut merekrut pemain dari luar Prancis. Terhitung selama tahun 1930-an, tim - tim profesional Prancis pada musim tersebut, terdapat 20 hingga $35 \%$ pemain asing, bahkan banyak yang dinaturalisasi. Terdapat juga beberapa pemain dari negara jajahan yang bermain untuk Prancis (Dietschy, 2012).

Jika peneliti menarik dari perspektif imigrasi, Tim sepak bola nasional Perancis, telah memiliki pemain yang memiliki keturunan di luar prancis dengan kuantitas pemain yang cukup banyak, Fakta lainnya ialah pemainpemain tersebut berasal dari 19 negara berbeda (seperti pada tabel 1), terbanyak dari semua tim sepak bola nasional sepanjang sejarah dunia. Mayoritas dari pemain-pemain tersebut ini lahir di bekas koloni Perancis seperti (Prancis) Aljazair, (Prancis) Maroko dan Senegal, atau pindah ke Prancis 'metropolitan' dari Prancis 'd'outre-mer' (peninggalan kerajaan kolonial Perancis) seperti Guadeloupe, Martinik dan Kaledonia Baru. Karena wilayah bekas jajahan Prancis ini secara administratif merupakan bagian dari Perancis, orang yang lahir di negara-negara ini secara otomatis memperoleh kewarganegaraan Prancis. Koneksi tersebut yang digunakan saat era 1930-an (Campenhout \& van Sterkenburg, 2019).

Komposisi pemain Tim Nasional Prancis yang multikultural sudah dimulai dari tahun 1958, bahkan awalanya pemain berketurunan di luar Prancis berasal dari negara tetangganya sendiri, seperti Raymond Kopa yang berasal dari Polandia dan Just Fontaine yang memiliki darah Spanyol. Di era pasca 1960-an, imigran menjadi salah satu faktor penting untuk sepak bola Prancis (Edlian, 2017) Terlebih saat itu, terdapat sebuah akademi pelatihan sepak bola nasional yang bernama Clairefontaine, pusat pelatihan tersebut mampu melakukan pencarian, perekrutan dan pelatihan bagi anak-anak imigran yang berasal dari banlieue 
Tabel 1. Data Pemain berketurunan di luar Prancis yang berpartisipasi untuk Tim Nasional Prancis di Piala Dunia.

\begin{tabular}{|c|c|c|c|}
\hline $\begin{array}{c}\text { Tim Nasional yang } \\
\text { diperkuat }\end{array}$ & $\begin{array}{c}\text { Tempat Lahir Pemain } \\
\text { (Negara) }\end{array}$ & $\begin{array}{c}\text { Partisipasi pada Piala } \\
\text { Dunia }\end{array}$ & Jumlah Pemain \\
\hline \multirow[t]{19}{*}{ Prancis } & Argentina & 1966 & 2 \\
\hline & Austria & 1938 & 1 \\
\hline & Kamerun & 2006,2018 & 2 \\
\hline & (Pranics) Aljazair & $\begin{array}{c}1930,1934,1938 \\
1954,1958,1978 \\
1982,1986\end{array}$ & 15 \\
\hline & (Prancis) Guyana & $1938,2006,2010$ & 3 \\
\hline & (Prancis) Maroko & 1954, 1958, 1978, 1982 & 4 \\
\hline & (Prancis) Sudan & 1982,1986 & 2 \\
\hline & Jerman & 1934,1938 & 4 \\
\hline & Ghana & 1998,2002 & 2 \\
\hline & Guadelope & $\begin{array}{l}1978,1982,1998, \\
2002,2006,2018\end{array}$ & 7 \\
\hline & Luksemburg & 1938 & 1 \\
\hline & Martinik & $1954,1978,1982$ & 3 \\
\hline & Kaledonia Baru & 1998 & 1 \\
\hline & Senegal & $\begin{array}{c}1998,2002,2006 \\
2010,2014 \\
\end{array}$ & 5 \\
\hline & Spain & 1986 & 1 \\
\hline & Swiss & 1934,1938 & 2 \\
\hline & Uruguay & 1938 & 1 \\
\hline & Zaire & $2002,2006,2010,2018$ & 4 \\
\hline & Lahir di Laut & 2014 & 1 \\
\hline
\end{tabular}

Sumber: Campenhout \& van Sterkenburg, 2019

(daerah pinggiran).

Peneliti juga menemukan fakta bahwa dalam menemukan kemampuan - kemampuan yang diinginkan oleh pelatih dari perekrutan pemain imigran tersebut, kemampuan tersebut mampu dilihat dari negara atau regional asalnya. Hal tersebut disampaikan oleh Steven Paulle, salah seorang pemain sepak bola berkewarganegaraan Prancis yang pernah bermain untuk PSM Makassar dan Persija Jakarta, dalam wawancaranya bersama penulis. Dalam hal itu, Steven Paulle menyampaikan jika pelatih menginginkan pemain yang memiliki tenaga yang kuat yang kebanyakan didapat oleh pemain yang berkulit hitam, kebanyakan dari pelatih akan mencari ke Afrika atau Karibia. Selain itu, pemain yang juga dibutuhkan pelatih ialah pemain yang lebih sedikit kecil posturnya namun memiliki kecepatan dan Teknik yang baik, biasanya terdapat di Afrika Utara, tepatnya di Maroko dan Aljazair (Steven Paulle, 5 Mei 2019).

Sebenarnya, Perekrutan pemain imigran ini juga bergantung pada Pemerintahan yang menjabat di Prancis. Hal itu terjadi saat Nicolas Sarkozy (Presiden Prancis 20072012) menjabat sebagai Presiden, Bagaimana federasi sepak bola Prancis (FFF) diharuskan untuk membatasi jumlah pemain keturunan Arab dan Afrika di Timnas pasca Piala Dunia 2010 hanya 30 persen saja. Namun, pada rentang waktu 2012-2017, Presiden Hollande mulai meretas isu mayoritas-minoritas di Prancis dengan kebijakan-kebijakannya akan menghukum pelaku rasis yang berdampak pada membaiknya situasi Timnas Prancis (Saragih, 
2018).

Peneliti menganalisa berdasarkan konsep multikulturalisme, Hasil pengamatan peneliti mencatat bahwa Sepak bola bukan hanya dianggap sebagai olah raga, melainkan cerminan dari keadaan masyarakat Prancis (Beydoun, 2018). Maka dari itu, kesuksesan Perancis di Piala Dunia, baik 1998 maupun 2018 bukan hanya menjadi kejayaan Prancis di kancah sepak bola Eropa maupun Dunia, tapi juga kesuksesan integrasi antara imigran dengan masyarakat lokal Perancis. Serta pemain-pemain imigran telah meneguhkan identitas nasional mereka tidak hanya sebagai warga Perancis, tetapi juga sebagai pahlawan terutama bagi persepakbolaan Perancis. Hal tersebut juga menunjukkan bahwa selalu terjadi perubahan ke arah positif tentang bagaimana masyarakat Perancis dalam menanggapi eksistensi pesepakbola berketurunan imigran di Perancis (Edlian, 2017).

Secara analisis konsep komunikasi lintas budaya yang menjadi aspek dari multikulturalisme, Sepak bola juga berperan penting dalam mengubah citra dan nasib dari para pemain berketurunan imigran Afrika, Dalam aplikasi hambatan komunikasi lintas budayanya, para pemain berketurunan tersebut kerap menjadi korban stereotype. Hal tersebut dikarenakan sebagian besar dari mereka merupakan anak Banlieue (daerah pinggiran) yang memiliki citra sebagai anggota geng, penjahat, dan calon teroris. Mereka dianggap sebagai "imigran" meskipun banyak dari mereka adalah warga generasi kedua dan ketiga yang lahir di Prancis. Maka tak heran sepak bola mampu mengubah pandangan masyarakat terhadap mereka (Ware, 2015).

Selain itu juga, para imigran kerap menjadi korban diskiriminatif dikarenakan tidak mampu mengikuti sistem atau aturan yang berlaku di Prancis. Mengutip pada Airin Miranda, Salah seorang Dosen Fakultas Ilmu Pengetahuan Budaya Program Studi Sastra Prancis Universitas Indonesia, dalam wawancaranya Bersama peneliti penelitian ini beliau mengatakan bahwa:

"Jadi, mereka (minoritas) memang rentan menjadi korban stereotype, rasisme, dan sebagainya, karena kegagalan integrasinya, masalahnya sih itu aja kalau menurut saya. Prancis itu harus mengubah cara integrasinya, mereka jangan bilang integrasi kalo nyatanya yang dilakukan adalah asimilasi. Tidak bisa. Jadi, orang Prancis itu harus Laicite, harus nasionalis, dan harus republika". (Airin Miranda, 14 Maret 2019).

Dampak lain yang dirasakan ialah prestasi Prancis dalam sepak bola dengan tim yang multietnis mampu untuk membangun kesadaran nasional untuk mempersatukan seluruh masyarakat tersebut atas dasar nasionalisme. Serta turnamen-turnemaen sepak bola yang diikuti oleh timnas Prancis tersebut juga mampu menumbuhkan identitas kolektif dari suatu bangsa (Edlian, 2017).

Peneliti juga meneliti bahwa Identitas nasional yang kolektif ini menjadi sebuah bukti bahwa komunikasi lintas budaya yang terjadi di Prancis bisa dikatakan terjalin dengan baik dan menjadi bukti bahwa integrasi sosial berjalan di antara masyarakat. Proses komunikasi tersebut terjadi karena media mampu secara metafora menyampaikan pesan tentang identitas nasional kepada masyarakat. Saat sepak bola menjadi sangat terkenal di kalangan masyarakat Prancis, di masa itu sepak bola berpatisipasi dalam pemberitaan mengenai identitas nasional. Selain itu juga, sepak bola mampu menjadi alat untuk menunjukkan bukti nasionalisme bagi suatu bangsa.

Peneliti juga menambahkan pernyataan dari salah satu narasumber yang merupakan pemain sepak bola Prancis, Steven Paulle. Ia mengatakan bahwa sepak bola sebenarnya bisa menjadi solusi dari permasalahan isu multikultural dikarenakan sebagai berikut: "in France we grow up together, some Muslim, some Jew, so for football player very easy to adopt, and that's very good in the football, I think that's one of the best, actually for integration, is the wins Collective, not individual. When you 
go together this kind of sport and very popular so you have lots of culture together, this is very good, you learn you start to understand how it works it's a good also. I think of course, clearly one of solution, not only football, but sports, it's very important to multicultural society and for education." (Steven Paulle, 5 Mei 2019).

Walaupun begitu, peneliti juga mengamati bahwa prestasi yang didapatkan dari sebuah keberagaman tidak serta merta membuat jalannya situasi multikultural di Sepak bola Prancis terlihat elok, Rasisme juga terjadi dalam sepakbola di Prancis. Salah satu tantangan yang harus dihadapi multikultur Prancis ialah tantangan Politik dari Front Nasionalis atau Partai Sayap Kanan Prancis yang dipimpin oleh Jean - Marie Le Pen.

Peneliti menganalisa bahwa terdapat hambatan komunikasi lintas budaya yang teraplikasikan dalam permasalahan ini, tergambar dalam situasi saat partai sayap kanan Prancis melakukan penolakan kepada kehadiran Timnas Prancis yang multikultural. Hambatan tersebut terpalikasian saat adanya prasangka yang dilakukan oleh Jean - Marie Le Pen terhadap fenomena black-blancbeur yang tidak sesuai dengan dasar dan idealisme yang dimiliki oleh Negara Prancis. Hambatan tersebut juga ditambah dengan adanya prasangka terhadap keberagaman yang dimiliki oleh Tim Nasional Prancis dianggap hanyalah buatan saja, anggapan (prasangka) tersebut juga menyudutkan para pemain Tim Nasional Prancis khususnya yang berketurunan imigran berkulit hitam yang dianggap hanya berjuang untuk mendapatkan trofi piala dunia, bukan untuk negara Prancis itu sendiri. Dalam prasangkanya, Le Pen juga mempersoalkan rasa nasionalisme yang dimiliki oleh para pemain imigran di Tim Nasional Prancis. Dalam pikiran Le Pen, Tim Nasional Prancis diperkuat oleh bangsa yang berkulit putih. Namun pada akhirnya, Timnas Prancis era 1998 (tertera pada gambar 1) mampu membuktikan bahwa argumen tersebut salah dengan prestasi yang didapatkan oleh timnas Prancis tersebut

\section{(Edlian, 2017).}

Permasalahan di atas jika merujuk pada bagian konsep multikulturalisme, terdapat karakteristik yang teraplikasikan yakni adanya integrasi sosial tumbuh dikarenakan adanya desakan atau depedensi dalam permasalahan ekonomi, serta adanya sistem politik yang didominasi oleh suatu kelompok atas kelompokkelompok yang lain. Integrasi sosial sebagai fungsi dari komunikasi lintas budaya menjadi sebuah tuntutan bagi kehidupan yang memiliki situasi multikulturalisme agar dapat menerima perbedaan latar belakang budaya, namun jika mengingat kembali alasan dari kedatangan para imigran ke Prancis salah satu alasan terbesarnya ialah ketergantungan ekonomi, Hal tersebut yang membuat kebanyakan imigran menjadikan sepak bola sebagai profesi mereka. Konsep yang teraplikasikan selanjutnya ialah sistem politik yang didominasi masyarakat Prancis berkulit putih membuat sentimen negatif terhadap kaum imigran semakin besar. Hal tersebut yang membuat sistem integrasi sebagai bentuk respons atas situasi multikultural di Prancis ini terlihat lebih menonjolkan sisi asimilasinya ketimbang mencoba mengintegrasikan masyarakat Prancis dan Imigran.

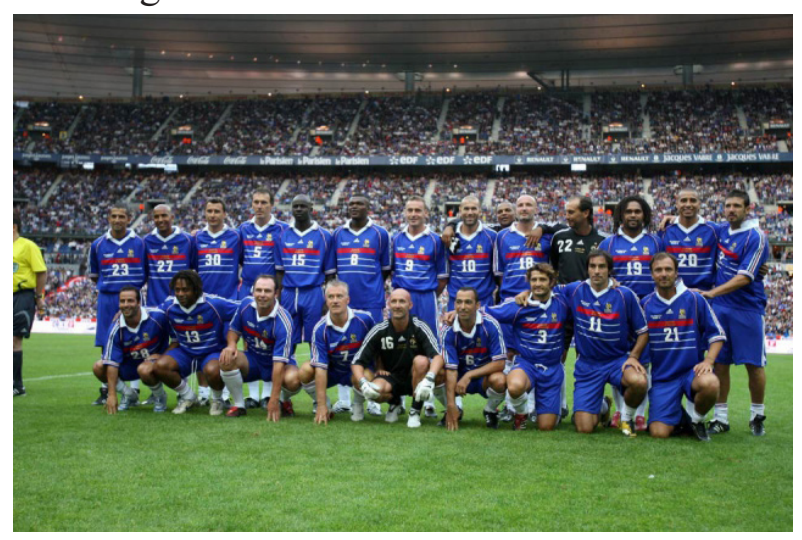

Gambar 1. Skuad Tim Nasional Prancis pada Piala Dunia 1998 yang di dominasi oleh pemain berketurunan imigran Afrika.

(Sumber: Dietschy, 2012).

Peneliti juga menganalisa dalam aplikasi komunikasi lintas budaya yang menjadi aspek penting dalam konsep multikulturalisme, Fungsi integrasi sosial dan identitas sosial 
teraplikasikan di dalam sepak bola Prancis. Hal tersebut terlihat bagaimana sepak bola mampu menjadi kendaraan para imigran untuk berintegrasi atau jalan pintas para imigran untuk naik kelas sosial. Jika berkaca apa yang terjadi pada tahun 1998, Timnas Prancis yang memenangkan Piala Dunia kerap disebut sebagai tim "black-blanc-beur" (keturunan kulit hitam - kulit putih - arab). Frasa tersebut juga digunakan sebagai bukti bahwa Prancis sukses untuk mengaplikasikan keuniversalan dalam republiknya. Dengan cara menjadikan pemain berketurunan imigran tersebut warga Negara Prancis dan mampu membela negaranya. Hal tersebut juga yang mampu meminimalisir adanya hambatan komunikasi lintas budaya yaitu etnosentris yang dilakukan oleh masyararakat terhadap para imigran, terutama yang menjadi pemain sepak bola professional (Edlian, 2017).

Hal tersebut didukung oleh pernyataan dari Justinus Lhaksana, salah seorang pengamat sepak bola internasional yang sekarang menjadi sportcaster di Bein Sports Indonesia. Beliau mengatakan sepak bola merupakan salah satu cara atau pekerjaan agar imigran dapat bertahan hidup atau survive di kehidupannya, terlebih infrastruktur, akademi sepak bola, hingga scouting di Prancis juga memiliki kualitas yang tinggi. Sehingga membuat bakat dari para imigran mudah tercium oleh para pencari bakat di Eropa, khususnya di Prancis (Justinus Lhaksana, 26 Februari 2019) .

Peneliti mengamati bahwa adanya Identitas sosial yang teraplikasikan dari situasi Para pemain berketurunan imigran Afrika yang tidak malu untuk menunjukkan identitas mereka. Bahkan menjadi keunikan tersendiri bagi Sepak Bola Prancis, khususnya Tim Nasionalnya. Hal tersebut dikarenakan keberhasilan para imigran dan keturunannya untuk berintegrasi dengan kultur Prancis dan tekad dari masyarakat Prancis untuk membuka diri kepada para imigran. Terlebih memang sudah banyak yang menyadari bahwa Prestasi Prancis dari dahulu itu bergantung pada kehadiran para pemain imgran itu sendiri (Hindratmo, 2018) .

Terlepas dari keunikan serta dampak positif yang terdapat dari keberagaman latar belakang budaya para pemain berketurunan imigran di Timnas Prancis, namun dapat dikatakan bahwa prestasi Prancis pada Piala Dunia FIFA 2018 hanyalah sebagai momentum persatuan semata, bukan menjadi alat pemersatu rakyat Prancis. Semua orang sejenak dibuat melupakan tentang perbedaan, semua orang tenggelam pada kebahagiaan atas kejayaan Tim Ayam Jantan (Julukan Timnas Prancis) di Rusia. Namun, saat segala euforia dan perayaan kemenangan tersebut berakhir, maka berakhir pula momen tersebut. Setelah kemenangan tersebut, kembali banyak kasus rasial yang terjadi, baik dalam kehidupan sehari-hari masyarakat Prancis, maupun secara spesifik dalam persepak bolaan Prancis.

Hal tersebut pun juga dirasakan oleh pemain Prancis, dikutip dari Khaled A. Beydoun, SeorangPemain sepakbolaberkewarganegaraan Prancis bernama Karim Benzema pernah berkata "If I score, I'm French. If I don't, I'm an Arab." (Beydoun, 2018). Dengan begitu peneliti menganalisa bahwa sepak bola belum sepenuhnya mampu menjadi pengubah situasi ke arah yang positif dalam isu multikultural di Prancis. Masih banyak masyarakat Prancis yang membawa permasalahan isu multikultural secara kehidupan sosial masyarakat ke dalam lingkup sepak bolanya. Salah satunya adalah stigma yang menyudutkan kaum imigran.

Penggambaran situasi tersebut juga didukung oleh pernyataan dari Airin Miranda, Salah seorang Dosen Fakultas Ilmu Pengetahuan Budaya Program Studi Sastra Prancis Universitas Indonesia, dalam wawancaranya Bersama peneliti penelitian ini. Beliau mengatakan bahwa sepak bola di Prancis hanya bisa menjadi momen pemersatu rakyat, namun belum bisa untuk solusi dari isu multikulturalisme, hal tersebut terjadi karena antusias dan euforia itu ada hanya saat Tim Nasional Prancis menerima kemenangan, namun hal itu tidak terjadi saat Tim Nasional 
Prancis memasuki fase yang tidak mengenakkan bagi publik sepak bola Prancis (Airin Miranda, 14 Maret 2019).

\section{SIMPULAN}

Berdasarkan pada hasil penelitian di atas, untuk menjawab rumusan masalah peneliti menyimpulkan bahwa Tim Nasional Prancis menggambarkan / merepresentasikan bahwa dalam situasi multikultural dalam kehidupan sepak bola Prancis ini mampu menghadirkan simbiosis mutualisme yang terjadi antara imigran dan sepak bola Prancis. Simbiosis tersebut ditunjukkan saat para imigran menggunakan sepak bola sebagai cara mereka untuk bisa berbaur dan mendekatkan diri mereka kepada masyarakat Prancis, sepak bola menjadi alat para imigran untuk bisa terintegrasi dengan masyarakat serta mampu menjadi alat mereka untuk menunjukkan identitas tanpa ada rasa takut dengan intimidasi atau diskriminasi yang berpotensi terjadi. Sebaliknya, Prancis juga menyadari betul bahwa prestasi dalam bidang sepak bola di Negara tersebut sangat bergantung pada kehadiran pemain berketurunan imigran tersebut. Sehingga Federasi Sepak bola Prancis memfasilitasi perekrutan pemain berketurunan imigran tersebut. Namun, terlepas dari itu semua, sepak bola tetaplah hanyalah olah raga biasa. Olah raga yang mampu mengundang emosi para penontonnya, membuat para pendukungnya lupa dengan perbedaan yang ada di antara mereka. Sepak bola belum bisa menjadi pemersatu untuk isu multikultural secara masif bagi masyarakat Prancis, namun bisa menjadi penghibur sejenak bagi masyarakat Prancis di tengah kasus rasial yang terus terjadi. Maka boleh dikatakan bahwa sepak bola mampu menjadi representasi dari situasi sebenarnya yang terjadi pada kehidupan multikultural di Prancis.

\section{DAFTAR PUSTAKA}

Bernard, F., Bisson, T., Popkin, J. D., Flower, J., Blondel , J., Fournier , G., Wright, G. (2019, February 6). France. Retrieved
March 20, 2019, from Encyclopedia Britannica.com: https://www. britannica.com/place/France

Beydoun, K. A. (2018). Les Bleus and Black: A Football Elegy to French Colorblindness. 103 Minnesota Law Review 20, 2018. Retrieved from https://papers.ssrn.com/sol3/papers. cfm?abstract id $=3501260$

Campenhout, G. V., \& van Sterkenburg, J. (2019). The diversification of national football teams: Using the idea of migration corridors to explore the underlying structures of nationality changes amongst foreignborn players at the football World Cup. International Review for the Sociology of Sport 1-26. doi:https://doi. org/10.1177/1012690219892849

Dewantara, A. W. (2019). Bhinneka Tunggal Ika Sebagai Model Multikulturalisme Khas Indonesia. Seminar Nasional KeIndonesiaan I "Multikulturalisme Dalam Bingkai Ke-Indonesiaan Kontemporer". Retrieved from http:// conference.upgris.ac.id/index.php/snk/ article/view/570/316

Dhamayanti, M. (2015). Komunikasi Lintas Budaya Etnis India, Etnis China Serta Pribumi Di Kampung Lubuk Pakam. Jurnal Ilmiah Komunikasi MAKNA, 6(1), Februari-Juli 2015. doi:http:// dx.doi.org/10.30659/jikm.6.1.13-21

Dietschy, P. (2012, June 19). Football et immigration en France. Retrieved from Musée national de l'histoire de l'immigration |: http://www.histoireimmigration.fr/dossiers-thematiques/ integration-et-xenophobie/football-etimmigration-en-france

Edlian, I. (2017). Integrasi Pesepak Bola Imigran Maghribi di Prancis (19382010). Institutional Repository UIN Syarif Hidayatullah Jakarta - 02 Fakultas Adab dan Humaniora - 0220 Sejarah dan Kebudayaan Islam. Retrieved from http://repository.uinjkt. 
ac.id/dspace/handle/123456789/37462

Hartley, J. (2010). Communication, Cultural, and Media Studies: Konsep Kunci. Yogyakarta: Jalasutra.

Hindratmo, N. (2018, July 19). Timnas Sepak Bola Prancis: Sepak Terjang Keberagaman. Retrieved from Kumparan: https://kumparan. $\mathrm{com} /$ nefertiti-hindratmo/timnassepakbola-prancis-sepak-terjangkeberagaman-27431110790548877

Ismoyo, P. J. (2017). Islamofobia Di Prancis: Diskriminasi Perempuan Muslim. Jurnal Cakrawala, 5(2). (2016). Retrieved from https://ejournal.uksw. edu/cakrawala/article/view/667

Krasnoff, L. S. (2016). Devolution of Les Bleus as a symbol of a multicultural French future. Soccer \& Society Volume 18, 2017 - Issue 2-3: The State of the Field: Ideologies, Identities and Initiatives. doi:http://dx.doi.org/10.1080/1466097 0.2016 .1166775

Mubit, R. (2016). Peran Agama Dalam Multikulturalisme Masyarakat Indonesia. Epistemé, 11(1), Juni 2016. doi:10.21274/epis.2016.11.1.163-184

Muhdaliha, B., \& Arlena, W. (2017). Malay, China And India Ethnicities Representation(CaseStudy:Etnography and Manga Matrix Analysis, on Upin Ipin Animation Character). WACANA, 16(1), Juni 2017. Retrieved from http:// journal.moestopo.ac.id/index.php/ wacana/article/view/10/2

Nazir, M. (2009). Metode Penelitian. Bogor, Indonesia: Ghalia Indonesia.

Neuman, W. L. (2017). Metodologi Penelitian Sosial : Pendekatan Kualitatif dan Kuantitatif. Jakarta, Indonesia: PT. Index.
Nurdin, M. A. (2015). Kegagalan Politik Multikulturalisme dan Pelembagaan Islamofobia di Negara-Negara Barat. Jurnal Ilmu Ushuluddin, 2(4), JULI 2015. Retrieved from http:// journal.uinjkt.ac.id/index.php/ilmuushuluddin/article/view/4841

Prayoga, K. (2016). Komunikasi Lintas Budaya Dalam Pengintegrasian Penyuluh Pertanian Di Asia Tenggara. Prosiding - Seminar Nasional Pembangunan Pertanian 2016-Universitas Brawijaya. Retrieved from http://fp.ub.ac.id/ semnas/Paper/68_komunikasi_lintas budaya-kadung_\%28437-444\%29.pdf

Saragih, A. (2018, August). Emmanuel Macron, Piala Dunia 2018, dan Merayakan Keragaman. Retrieved from Qureta: https://www.qureta.com/ post/emmanuel-macron-piala-dunia2018-dan-merayakan-keragaman

Sugiyono, P. D. (2016). Metode Penelitian - Kuantitatif, Kualitatif, dan R\&D. Bandung, Indonesia: Penerbit Alfabeta. Sugiyono, P. D. (2016). Metode Penelitian - Kuantitatif, Kualitatif, dan R\&D. Bandung: Penerbit Alfabeta.

Ware, L. (2015). Color-blind Racism in France: Bias Against Ethnic Minority Immigrants. Washington University Journal of Law \& Policy Volume 46 Emerging Ideas in Law. Retrieved from https://openscholarship.wustl.edu/law_ journal_law_policy/vol46/iss1/11/

Wicaksono, M. A. (2017). Dinamika Imigran Muslim di Perancis melalui Ruang Publik pada Pemerintahan Nicholas Sarkozy. Jurnal Transformasi Global, 4(2). Retrieved from https:// transformasiglobal.ub.ac.id/index.php/ trans/article/view/79. 